\title{
Utilização do sistema de avaliação do potencial de uso urbano das terras no diagnóstico ambiental do município de Santa Maria - RS
}

\author{
Environmental diagnostic of Santa Maria county - RS, Brazil through the urban land use potential system
}

\author{
Fabrício de Araújo Pedron ${ }^{1}$ Ricardo Simão Diniz Dalmolin ${ }^{2}$ Antonio Carlos de Azevedo \\ Everton Luis Poelking ${ }^{3}$ Pablo Miguel $^{4}$
}

\section{RESUMO}

A expansão urbana acelerada tem provocado diversos impactos negativos ao ambiente. A necessidade de novas metodologias que permitam um planejamento mais adequado dos recursos naturais é cada dia mais evidente. O objetivo deste trabalho foi realizar um diagnóstico ambiental em áreas urbanas de Santa Maria - RS, determinando-se os conflitos de uso das terras através, do Sistema de Avaliação do Potencial de Uso Urbano das Terras (SAPUT). Foram utilizados produtos e técnicas de sensoriamento remoto $e$ geoprocessamento de imagens. Os problemas de uso indevido das terras identificados estão relacionados com a fragilidade do material geológico e do recurso solo. Até 33\% da área vem apresentando utilização acima do seu potencial devido ao seu uso inadequado para construções e agricultura urbana.

Palavras-chave: levantamento de solos, pedologia, solos, uso das terras, sensoriamento remoto.

\section{ABSTRACT}

The accelerated urban expansion has promoted several negative impacts on the environment. The need of new methodologies that allows a more appropriate planning of the natural resources grows constantly. The objective of this research was to accomplish an environmental diagnostic in urban areas of Santa Maria - RS, Brazil, determining the land use conflicts through the Urban Land Use Potential System. Products and techniques of remote sensing and image geoprocessing were used. Improper land use is related to the fragility of the geological material and soil resources. Up to $33 \%$ of the area is used above its potential with inadequate construction and urban agriculture.

Key words: soil survey, pedology, soil, land use, remote sensing.

\section{INTRODUÇÃO}

A urbanização no Brasil vem ocorrendo de forma desordenada, com muitas implicações negativas. Uma delas é o aspecto ambiental, o qual tem sofrido forte pressão devido ao uso inadequado do espaço natural. A grande concentração humana em áreas cada vez mais alteradas, caracterizadas pela falta de estrutura e saneamento básico, tem afetado negativamente a qualidade de vida nos centros urbanos (CALLAI, 1993; ROSSATO, 1993; DA COSTA \& CINTRA, 1999; BRASIL, 2004).

A expansão urbana acelerada torna-se um desafio para os pesquisadores, requerendo novos métodos de análise e fontes de dados e informações. $\mathrm{O}$ entendimento da dinâmica do crescimento urbano de uma região é imprescindível ao planejamento de ações construtivas que visam a organização destes ambientes. Para tanto, de acordo com MILLER \& SMALL (2003), novas tecnologias e metodologias devem ser adotadas, capazes de simplificar a obtenção de informações, de forma rápida, eficiente e com menor gasto de recursos. O sensoriamento remoto e o geoprocessamento são ferramentas adequadas quando associadas ao levantamento dos solos e à determinação do potencial de uso das terras (ASSAD, 1995).

O solo é um recurso natural de suma importância na sustentação dos diversos ecossistemas,

${ }^{1}$ Departamento de Solos, Universidade Federal de Santa Maria (UFSM), Santa Maria, Rio Grande do Sul, RS, Brasil, 97105-900, Campus UFSM, Departamento de Solos, prédio 42. E-mail: fapedron@mail.ufsm.br. Autor para correspondência.

${ }^{2}$ Departamento de Solos, UFSM, Santa Maria, RS, Brasil.

${ }^{3}$ Programa de Pós-graduação em Ciência do Solo (PPGCS), UFSM, Santa Maria, RS, Brasil.

${ }^{4}$ Curso de Agronomia, UFSM, Santa Maria, RS, Brasil. 
sendo o elemento chave na classificação do potencial de uso das terras (DENT \& YOUNG, 1993). O uso racional das terras exige o conhecimento prévio de suas características e limitações, as quais são obtidas através dos levantamentos pedológicos e de aspectos do meio físico, constituindo informações adequadas para a sua classificação. O Sistema de Avaliação do Potencial de Uso Urbano das Terras (SAPUT) se propõe a analisar e classificar áreas sob influência urbana quanto à sua capacidade de suportar determinada atividade humana com a mínima degradação das terras (PEDRON, 2005). O SAPUT é estruturado em quatro grupos de uso: descarte de resíduos, construções urbanas, agricultura urbana e preservação ambiental, os quais são agrupados em três classes de uso: adequada, restrita e inadequada, considerando as características e propriedades ambientais referentes a cada gleba de terra.

Com quase 150 anos de história, o município de Santa Maria apresenta 94,7\% da população urbana, conforme IBGE (2000). A expansão urbana em Santa Maria tem provocado a contaminação dos recursos hídricos, dos solos e a destruição da vegetação nativa (ROBAINA et al., 2001. URRUTIA, 2002). Os objetivos deste trabalho foram: 1 . realizar o levantamento semidetalhado de solos no perímetro urbano de Santa Maria, RS; 2. utilizar o SAPUT para avaliar o potencial de uso urbano das terras; e 3. determinar os conflitos de uso das terras na área de estudo, visando entender a dinâmica de uso atual do espaço físico e suas implicações ambientais.

\section{MATERIAL E MÉTODOS}

O trabalho foi realizado no perímetro urbano do município de Santa Maria (PUSM), Rio Grande do Sul (RS). O PUSM se constitui na área urbana e área de expansão urbana, compreendendo 12.548ha. Santa Maria localiza-se na região fisiográfica da Depressão Central, próxima à zona denominada de rebordo do Planalto, a $29^{\circ} 43^{\prime}$ de latitude sul e $53^{\circ}$ 49' de longitude oeste. O clima local, segundo a classificação de Köeppen, é do tipo Cfa, com precipitação média anual de $1700 \mathrm{~mm}$ e temperatura média anual de $18^{\circ} \mathrm{C}$, sendo a média das máximas do mês mais quente $32^{\circ} \mathrm{C}$ e das mínimas do mês mais frio de $9^{\circ} \mathrm{C}$ (BURIOL et al., 1979).

Inicialmente foi realizado o levantamento semidetalhado de solos da área de estudo, de acordo com os procedimentos da EMBRAPA (1995) e KLAMT et al. (2000). A descrição morfológica e coleta das amostras de solos foram efetuadas segundo LEMOS \& SANTOS (2002), enquanto as análises químicas e físicas foram realizadas conforme metodologia proposta pela EMBRAPA (1997). Os diferentes solos foram classificados segundo o Sistema Brasileiro de Classificação de Solos (EMBRAPA, 1999), até o quarto nível categórico, somados a estes informações sobre a classe textural, horizontes diagnósticos superficiais e relevo. O mapa digital final, na escala 1:25.000, foi denominado de plano de informação (PI) solo.

O PI geologia foi obtido pela digitalização das cartas geológicas de Camobi (MACIEL FILHO et al., 1988) e Santa Maria (MACIEL FILHO, 1990), nas escalas 1:50.000 e 1:25.000 respectivamente. Os dados do relevo e da rede de drenagem foram extraídos das cartas topográficas produzidas pela Diretoria do Serviço Geográfico do exército - DSG, folhas de Camobi - SO e Santa Maria - SE, com curvas de nível apresentando distância vertical de 10 metros e escala 1:25.000. A partir dos dados do relevo, foi produzido o PI declividades, dividido nas classes de $0-3,3-8,8-13,13-20,20$ -45 , 45-100 e acima de $100 \%$. Também com os dados do relevo foi gerado o PI topo de morro, através da ferramenta "extração de topos de morros" do aplicativo Spring, a qual permite a obtenção das áreas de preservação permanentes em morros, conforme a legislação ambiental (CONAMA, 2002).

Com os dados da rede de drenagem foram produzidos os PIs nascentes, buffer $30 \mathrm{~m}$ e buffer $200 \mathrm{~m}$ dos cursos d'água (zonas de segurança entorno dos cursos d'água que apresentam restrições de uso conforme legislação - CONAMA, 2002), através da ferramenta "mapa de distâncias" do Spring, a qual permite a extração de zonas com larguras especificadas (distâncias) em torno de um ou mais elementos do mapa, neste caso as nascentes d’água e a rede de drenagem. O PI áreas de preservação permanente (APP) foi baseado na Resolução n. 303 (CONAMA, 2002), pela sobreposição dos PIs: declividades, topo de morros, nascentes e buffer $30 \mathrm{~m}$.

O mapa de potencial de uso urbano das terras foi gerado pelo SAPUT, cuja estrutura básica pode ser visualizada na figura 1 . Informações dos solos, geologia, relevo, APP e buffer $200 \mathrm{~m}$, associados ao clima, geraram classes de potencial de uso urbano para os grupos descarte de resíduos, construções urbanas, agricultura urbana e preservação ambiental. No SAPUT, as classes de potencial de uso urbano são determinadas pela análise dos fatores restritivos referentes a cada grupo de uso e seu posterior enquadramento nos subgrupos. A simbologia é formada pelo número do subgrupo seguido pela letra do grupo. As classes “adequado, restrito e inadequado” são representadas pelas letras maiúsculas, minúsculas e ausência de letras, respectivamente. 


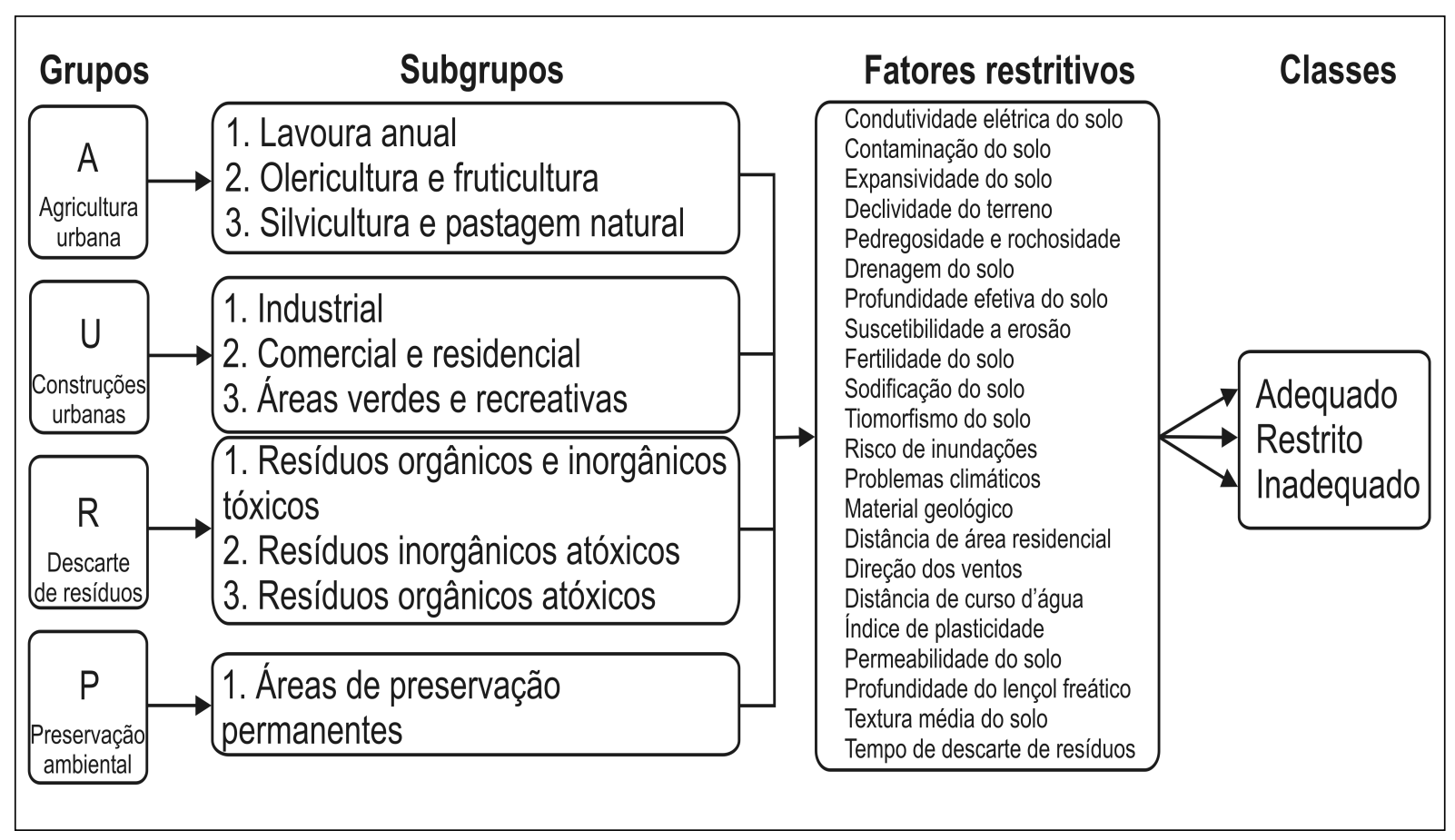

Figura 1 - Organograma do Sistema de Avaliação do Potencial de Uso Urbano das Terras - SAPUT (PEDRON, 2005).

O mapa de uso atual das terras foi gerado a partir da classificação multiespectral supervisionada da imagem do sensor ETM+ (Landsat 7), do ano de 2002. O método de classificação utilizado foi o "pixel a pixel”, através do classificador estatístico "MAXVER” (máxima verossimilhança) (INPE, 2003). Foram estabelecidas cinco classes de uso: urbano (todos os elementos artificiais característicos do meio urbano, assim como rodovias e estradas municipais), floresta (nativa e plantada), agricultura anual (culturas anuais), campo natural (pastagens naturais e capoeiras) e corpos d’água (arroios, córregos, lagos e barragens). Pequenos erros de classificação foram em partes corrigidos pela reambulação temática.

O mapa de conflitos de uso das terras para o PUSM foi gerado a partir do cruzamento dos mapas de potencial de uso urbano das terras e uso atual das terras, gerando dados numéricos e mapa que apresentam a situação ambiental de uso dos recursos naturais da área de estudo. Os diversos PIs considerados neste trabalho foram produzidos e manejados utilizando-se técnicas de sensoriamento remoto e geoprocessamento digital, através do aplicativo Spring - Sistema de Processamento de Informações Georeferenciadas (CAMARA et al., 1996), versão 4.0 .

\section{RESULTADOS E DISCUSSÃO}

Considerando a legenda dos solos e suas áreas, apresentadas na tabela 1 , bem como o mapa de solos (Figura 2A), observa-se que as classes de solos predominantes na área de estudo são Alissolos (44\%), Argissolos (25\%), Neossolos (8 \%) e Planossolos (23 $\%)$. As classes dos Alissolos e Argissolos juntas compreendem 69 \% da área, apresentando grande variabilidade ambiental, morfológica, física e química que afetam o seu potencial de uso (PEDRON et al., 2004). Ambas as classes apresentam alta suscetibilidade à degradação ambiental quando manejadas inadequadamente, principalmente devido à erosão hídrica, pela presença de mudança textural, conforme indicado pela ocorrência de voçorocas nessas classes de solos no município (MACIEL FILHO, 1990), tornando esses ambientes de risco à ocupação humana (ROBAINA et al., 2001). 
Tabela 1 - Legenda das classes de solos do perímetro urbano de Santa Maria, RS.

\begin{tabular}{|c|c|c|c|}
\hline Classes de solos & Símbolos & $\begin{array}{l}\text { Áreas } \\
\text { (ha) }\end{array}$ & $\begin{array}{l}\text { Potencial de uso urbano dos } \\
\text { solos }\end{array}$ \\
\hline $\begin{array}{l}\text { Alissolo Crômico argilúvico típico textura arenosa/média } \\
\text { chernozêmico relevo suave ondulado a ondulado }\end{array}$ & ACt 1 & 107 & $3 u / 2 a$ \\
\hline $\begin{array}{l}\text { Alissolo Crômico argilúvico típico textura arenosa/argilosa A moderado } \\
\text { relevo suave ondulado }\end{array}$ & ACt 2 & 280 & $3 u / 2 a$ \\
\hline $\begin{array}{l}\text { Alissolo Crômico argilúvico abrúptico textura arenosa/argilosa A } \\
\text { moderado relevo suave ondulado }\end{array}$ & ACt 3 & 74 & $3 \mathrm{u} / 2 \mathrm{a}$ \\
\hline $\begin{array}{l}\text { Alissolo Crômico argilúvico típico textura média/argilosa A } \\
\text { proeminente relevo suave ondulado }\end{array}$ & ACt 4 & 362 & $3 \mathrm{r} / 2 \mathrm{u} / 1 \mathrm{a}$ \\
\hline $\begin{array}{l}\text { Alissolo Hipocrômico argilúvico abrúptico textura arenosa/média A } \\
\text { moderado relevo ondulado }\end{array}$ & APt 1 & 1751 & $3 \mathrm{r} / 2 \mathrm{u} / 2 \mathrm{a}$ \\
\hline $\begin{array}{l}\text { Alissolo Hipocrômico argilúvico típico textura média/argilosa A } \\
\text { proeminente relevo suave ondulado }\end{array}$ & APt 2 & 1653 & $2 \mathrm{r} / 2 \mathrm{u} / 2 \mathrm{a}$ \\
\hline $\begin{array}{l}\text { Alissolo Hipocrômico argilúvico abrúptico textura arenosa/média A } \\
\text { fraco relevo suave ondulado }\end{array}$ & APt 3 & 7 & $3 u / 3 a$ \\
\hline $\begin{array}{l}\text { Alissolo Hipocrômico argilúvico típico textura média/argilosa A } \\
\text { moderado relevo suave ondulado a ondulado }\end{array}$ & APt 4 & 956 & $3 \mathrm{u} / 2 \mathrm{a}$ \\
\hline $\begin{array}{l}\text { Alissolo Hipocrômico argilúvico abrúptico textura arenosa/média A } \\
\text { moderado relevo ondulado a forte ondulado }\end{array}$ & APt 5 & 76 & $3 u / 2 a$ \\
\hline $\begin{array}{l}\text { Alissolo Hipocrômico argilúvico típico textura média/argilosa A } \\
\text { proeminente relevo ondulado }\end{array}$ & APt 6 & 192 & $3 \mathrm{u} / 2 \mathrm{a}$ \\
\hline $\begin{array}{l}\text { Argissolo Amarelo distrófico arênico textura arenosa/argilosa A } \\
\text { moderado relevo suave ondulado }\end{array}$ & PAd & 107 & $3 \mathrm{r} / 2 \mathrm{u} / 1 \mathrm{a}$ \\
\hline $\begin{array}{l}\text { Argissolo Vermelho }- \text { Amarelo distrófico } \\
\text { arenosa/argilosa A fraco relevo suave ondulado }\end{array}$ & PVAd 1 & 838 & $3 \mathrm{u} / 2 \mathrm{a}$ \\
\hline $\begin{array}{l}\text { Argissolo Vermelho - Amarelo distrófico espessarênico textura } \\
\text { arenosa/média A proeminente relevo suave ondulado }\end{array}$ & PVAd 2 & 1544 & $3 u / 2 a$ \\
\hline $\begin{array}{l}\text { Argissolo Vermelho distrófico abrúptico textura arenosa/argilosa A } \\
\text { moderado relevo suave ondulado }\end{array}$ & PVd & 627 & $3 \mathrm{u} / 2 \mathrm{a}$ \\
\hline $\begin{array}{l}\text { Neossolo Regolítico eutrófico léptico textura média A chernozêmico } \\
\text { relevo ondulado }\end{array}$ & RRe 1 & 120 & $3 u / 2 a$ \\
\hline $\begin{array}{l}\text { Neossolo Regolítico eutrófico léptico textura arenosa a média A } \\
\text { proeminente relevo suave ondulado a ondulado }\end{array}$ & RRe 2 & 40 & $3 u / 3 a$ \\
\hline $\begin{array}{l}\text { Neossolo Regolítico psamítico léptico }+ \text { Neossolo Litólico eutrófico } \\
\text { típico relevo forte ondulado a escarpado }\end{array}$ & RRq + RLe & 692 & $1 \mathrm{P}$ \\
\hline $\begin{array}{l}\text { Neossolo Regolítico psamítico léptico + Neossolo Litólico eutrófico } \\
\text { típico relevo plano a suave ondulado }\end{array}$ & RRq + RLe p & 80 & $3 u / 2 a$ \\
\hline $\begin{array}{l}\text { Neossolo Flúvico psamítico típico textura arenosa A moderado relevo } \\
\text { plano }\end{array}$ & RUq & 36 & $3 u / 2 a$ \\
\hline $\begin{array}{l}\text { Planossolo Hidromórfico distrófico típico textura arenosa/argilosa A } \\
\text { proeminente relevo plano a suave ondulado }\end{array}$ & SGd 1 & 262 & $3 \mathrm{u} / 2 \mathrm{a}$ \\
\hline $\begin{array}{l}\text { Planossolo Hidromórfico distrófico típico textura média A proeminente } \\
\text { relevo plano a suave ondulado }\end{array}$ & SGd 2 & 37 & $3 u / 2 a$ \\
\hline $\begin{array}{l}\text { Planossolo Hidromórfico distrófico arênico textura arenosa/média A } \\
\text { proeminente relevo plano a suave ondulado }\end{array}$ & SGd 3 & 113 & $3 u / 2 a$ \\
\hline $\begin{array}{l}\text { Planossolo Hidromórfico distrófico típico textura média A proeminente } \\
\text { relevo plano }\end{array}$ & SGd 4 & 151 & $3 \mathrm{u} / 2 \mathrm{a}$ \\
\hline $\begin{array}{l}\text { Planossolo Hidromórfico eutrófico típico textura média/argilosa A } \\
\text { proeminente relevo plano }\end{array}$ & SGe & 2363 & $3 u / 2 a$ \\
\hline Corpos d’água & - & 80 & - \\
\hline
\end{tabular}

Ciência Rural, v.36, n.2, mar-abr, 2006. 
Os Neossolos do PUSM caracterizam-se pela espessura do horizonte superficial entre 20 a $40 \mathrm{~cm}$ sobre a rocha sã ou intemperizada, ocorrendo em relevo ondulado a escarpado no rebordo do Planalto, possuindo baixo potencial de uso (PEDRON, 2005). Os Planossolos Hidromórficos apresentam horizonte subsuperficial argiloso e ocorrem em áreas de banhado e em várzeas que são áreas de recarga dos aqüíferos locais (MACIEL FILHO, 1990), além de apresentarem limitações de drenagem e inundações.

Os dados referentes ao uso atual das terras (Tabela 2) mostram que a maior área é utilizada com campo natural (42\%) e uso urbano (33\%). O mapa do uso das terras é apresentado na figura 2B. A análise dos dados de uso das terras mostra que grande parte da área urbana concentra-se no eixo leste - oeste, devido à existência de limites físicos para expansão urbana no sentido norte - sul: a linha de morros da Serra Geral (ao norte) e as unidades militares e universidade federal (ao sul), além da disposição da ferrovia, instalada na região em 1885, a qual teve forte influência no crescimento de Santa Maria (URRUTIA, 2002). Notase a presença de florestas, principalmente nativa (20\%), em áreas de restrito acesso para produção agrícola e pecuária, como topo de morros e áreas com maior declividade, na porção norte do PUSM, junto ao rebordo do Planalto e nos morros residuais.

O levantamento das APP aponta que 19\% do PUSM enquadram-se nesse grupo. Considerando as normas do CONAMA (2002), percebe-se que há uma sub-estimativa das APP, visto que é impossível identificar e localizar todas as nascentes, vertentes e olhos d'água distribuídos nas mais diversas feições geomorfológicas existentes na área de estudo. No entanto, dentre as áreas de maior expressividade destacam-se os topos de morros com 7\% da área total e as matas ciliares com $11 \%$.

Os dados de potencial de uso urbano das terras (Tabela 2) mostram que a classe predominante foi a $3 u / 2 a(52 \%)$. Essa classe compreende terras que possuem fortes limitações ao grupo descarte de resíduos, sendo inadequadas para tal, e restritas ao uso urbano com áreas verdes e de recreações, no grupo construções urbanas, e ao uso com olericultura e fruticultura, no grupo agricultura urbana. O restante da área apresentou potencial limitado para descarte de resíduos orgânicos e inorgânicos atóxicos e uso restrito para construções urbanas do tipo residencial e comercial (27\%), sendo 20\% do PUSM classificado como área de preservação ambiental. Os fatores restritivos para estas classes são apresentados na tabela 3. O mapa de potencial de uso urbano das terras pode ser visualizado na figura $3 \mathrm{~A}$.

A forte limitação das terras quanto ao uso para descarte de resíduos está associada principalmente com a proximidade dos cursos d'água e com o material de origem. De acordo com a legislação (ABNT, 1997), aterros sanitários não podem ser instalados em uma faixa de 200m dos cursos d'água. Nesse caso, o mapa de potencial de uso foi cruzado com o PI buffer $200 \mathrm{~m}$, determinando as áreas inadequadas ao grupo descarte de resíduos.

O material geológico foi outro fator restritivo que limitou o uso com os grupos descarte de resíduos e construções urbanas. Na região, predominam formações sedimentares constituídas de arenitos, siltitos e argilitos. Na área de estudo, ocorrem tanto materiais geológicos impermeáveis, os quais não oferecem perigo ao uso urbano, pois não apresentam caráter aqüífero, quanto materiais permeáveis a semipermeáveis, os quais oferecem riscos de contaminação das águas subterrâneas (MACIEL FILHO, 1990).

Os dados referentes aos conflitos de uso (Tabela 2, Figura 3B) indicam que 22\% da área apresentam utilização adequada, conforme a estimativa da sua capacidade de uso gerada pelo SAPUT. Áreas que se encontram sob sub-utilização (45\%) compreendem, em grande parte, campos naturais que apresentam potencial para uso, principalmente, para construções urbanas e agricultura urbana, nos subgrupos 2 e 3 do SAPUT.

As áreas sob uso inadequado (33\%) se dividem em dois grupos. O primeiro, das APP, são áreas de manutenção do ecossistema natural que estão sendo utilizadas como lavouras anuais e perenes, campos naturais para criação de animais e empreendimentos urbanos. Estes resultados confirmam observações anteriores, na mesma região, de que a pressão antrópica sobre áreas naturais tem estado acima das legislações ambientais (PIROLI et al., 2002, PEDRON, 2005).

O segundo grupo são terras utilizadas para construções urbanas que apresentam limitações devido 
Tabela 2 - Áreas dos planos de informações estudados no trabalho, para o perímetro urbano de Santa Maria, RS.

\begin{tabular}{|c|c|c|}
\hline \multirow{2}{*}{ Planos de informação } & \multicolumn{2}{|c|}{ Áreas* } \\
\hline & ha & $\%$ \\
\hline \multicolumn{3}{|l|}{ Uso atual das terras } \\
\hline Urbano & 4.148 & 33 \\
\hline Floresta & 2.533 & 20 \\
\hline Agricultura anual & 564 & 4 \\
\hline Campo natural & 5.221 & 42 \\
\hline Corpos d’água & $82^{+}$ & 1 \\
\hline \multicolumn{3}{|l|}{ Áreas de preservação permanentes (APP) } \\
\hline Matas ciliares & 1.439 & 11 \\
\hline Nascentes e fontes naturais & 144 & 1 \\
\hline Topos de morros & 847 & 7 \\
\hline Áreas com declividades acima de $100 \%$ & 10 & 0 \\
\hline Áreas não consideradas APP & 10.108 & 81 \\
\hline \multicolumn{3}{|l|}{ Potencial de uso urbano das terras } \\
\hline $3 \mathrm{u} / 2 \mathrm{a}$ & 6.491 & 52 \\
\hline $3 \mathrm{r} / 2 \mathrm{u} / 1 \mathrm{a}$ & 423 & 3 \\
\hline $3 \mathrm{r} / 2 \mathrm{u} / 2 \mathrm{a}$ & 1.558 & 12 \\
\hline $2 \mathrm{r} / 2 \mathrm{u} / 2 \mathrm{a}$ & 1.497 & 12 \\
\hline 3u/3a & 32 & 0 \\
\hline $1 \mathrm{P}$ & 2.547 & 20 \\
\hline \multicolumn{3}{|c|}{ Potencial de uso urbano das terras x buffer de 200 m dos cursos d'água } \\
\hline $3 \mathrm{u} / 2 \mathrm{a}$ & 2.122 & 17 \\
\hline $3 \mathrm{r} / 2 \mathrm{u} / 1 \mathrm{a}$ & 189 & 2 \\
\hline $3 \mathrm{r} / 2 \mathrm{u} / 2 \mathrm{a}$ & 591 & 5 \\
\hline $2 \mathrm{r} / 2 \mathrm{u} / 2 \mathrm{a}$ & 674 & 5 \\
\hline 3u/3a & 0 & 0 \\
\hline 1P + áreas inadequadas ao descartes de resíduos & 8.972 & 72 \\
\hline \multicolumn{3}{|l|}{ Conflitos de uso das terras } \\
\hline Uso adequado das terras & 2.729 & 22 \\
\hline Sub-utilização das terras & 5.702 & 45 \\
\hline Uso inadequado das terras (super-utilização) & 4.117 & 33 \\
\hline
\end{tabular}

* A soma das porcentagens pode não igualar a 100 devido a erros de arredondamentos.

+ A diferença entre as áreas de corpos d’água das tabelas 1 e 2 é devido ao fato de a primeira apresentar dados extraídos de fotografias aéreas de 1996, utilizadas na confecção do mapa base para o levantamento de solos, sendo a segunda, obtida da imagem ETM+ 2002.

ao tipo de material geológico (aqüífero) e ao caráter hidromórfico dos solos. Em relação à geologia, destacam-se os arenitos da Formação Caturrita e o Membro Passo das Tropas da Formação Santa Maria, os quais se encontram potencialmente poluídos (MACIEL FILHO, 1990). Quanto ao caráter hidromórfico dos solos, destacam-se as áreas de várzea dos arroios Cadena e Ferreira, onde a ocupação urbana é bastante intensa. Nessas áreas, o ambiente oferece riscos à ocupação, como inundações, solapamentos e deslizamentos próximo às margens dos arroios, instabilidade para as construções e contaminação dos recursos naturais pelo descarte de resíduos provenientes das atividades humanas (BERGER, 2001; ROBAINA et al., 2001).

\section{CONCLUSÕES}

O mapa de solos do perímetro urbano de Santa Maria mostra que 69\% da área é constituída de Alissolos e Argissolos, os quais apresentaram restrições de uso para descarte de resíduos, construções urbanas e agricultura urbana. O Sistema de Avaliação do Potencial de Uso Urbano das Terras SAPUT, em sua primeira aproximação, apresentou boa potencialidade de uso na avaliação de diferentes terras no perímetro urbano de Santa Maria. No entanto, fatores restritivos e seus limites de valores podem ser ajustados para uma melhor funcionalidade e precisão ao que se propõem.

Ciência Rural, v.36, n.2, mar-abr, 2006. 


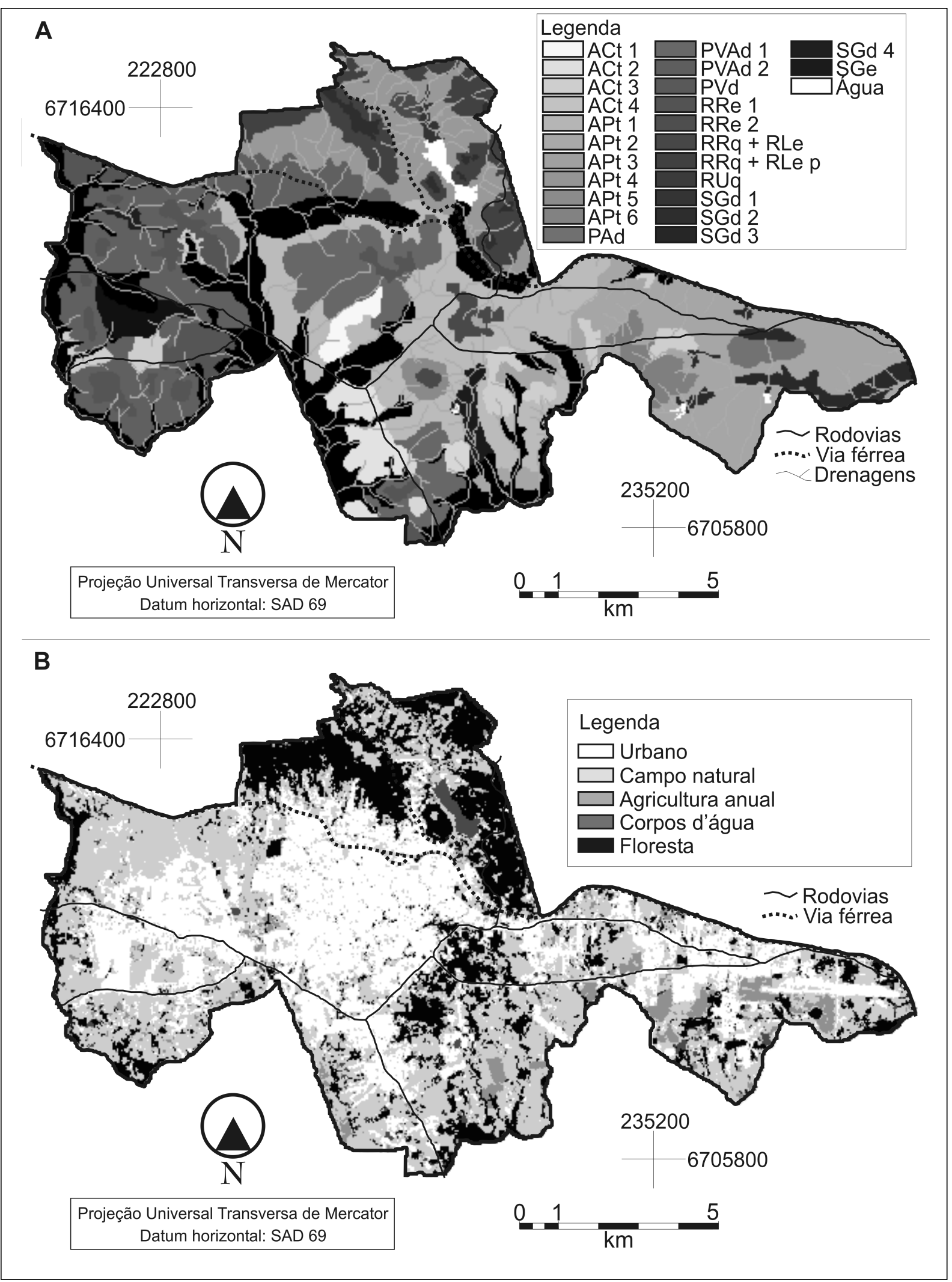

Figura 2 - Mapa de solos (A) e de uso atual das terras (B) do perímetro urbano de Santa Maria, RS.

Ciência Rural, v.36, n.2, mar-abr, 2006. 


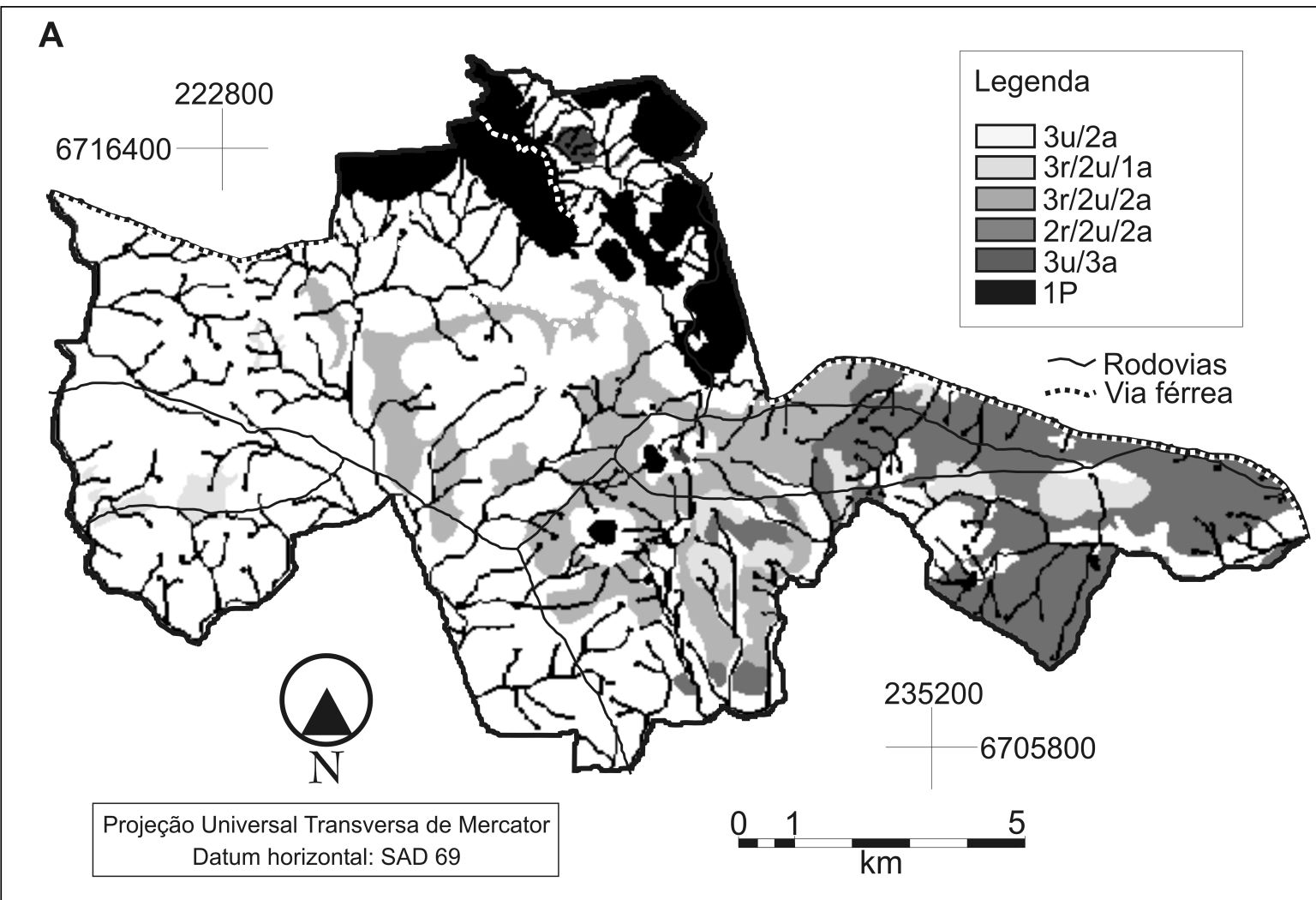

B

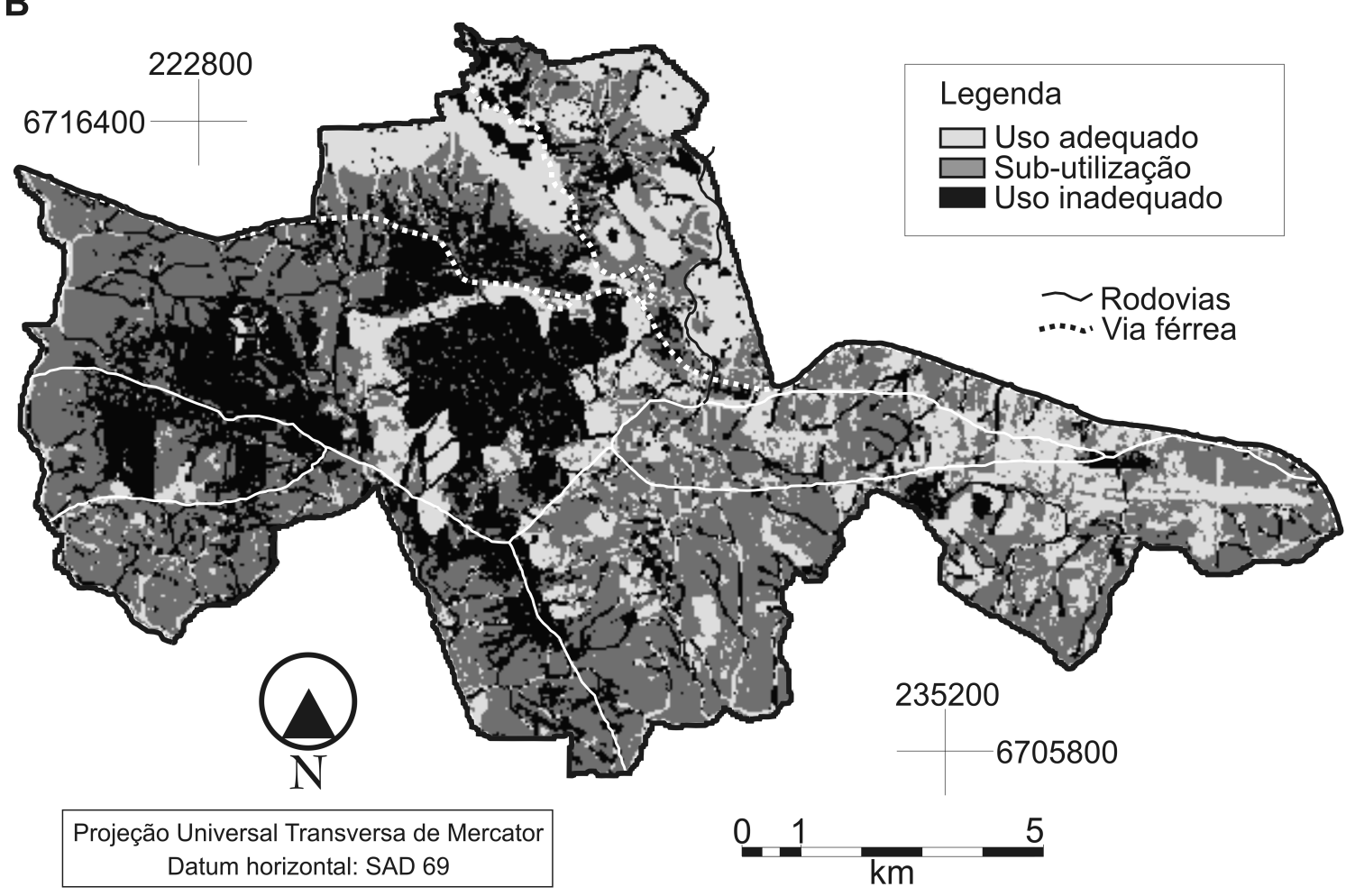

Figura 3 - Mapa de potencial de uso (A) e conflitos de uso urbano das terras (B) no perímetro urbano de Santa Maria, RS. 
Tabela 3 - Descrição dos fatores restritivos para cada grupo de uso das terras conforme o Sistema de Avaliação do Potencial de Uso Urbano das Terras - SAPUT.

\begin{tabular}{llll}
\hline & & \multicolumn{2}{c}{ Fatores restritivos por grupo de uso urbano das terras ${ }^{2}$} \\
Classes de potencial de uso ${ }^{1}$ & & Construções urbanas & Agricultura urbana \\
\hline $3 \mathrm{u} / 2 \mathrm{a}$ & - & $\mathrm{ps}, \mathrm{dr}, \mathrm{g}, \mathrm{d}, \mathrm{i}, \mathrm{pm}, \mathrm{r}$ & $\mathrm{dr}, \mathrm{e}, \mathrm{i}, \mathrm{d}, \mathrm{ct}, \mathrm{os}, \mathrm{u}$ \\
$3 \mathrm{r} / 2 \mathrm{u} / 1 \mathrm{a}$ & $\mathrm{t}, \mathrm{dr}, \mathrm{a}, \mathrm{td}, \mathrm{c}, \mathrm{ps}$ & $\mathrm{dr}, \mathrm{e}, \mathrm{ps}, \mathrm{dr}$ & $\mathrm{dr}, \mathrm{e}, \mathrm{d}, \mathrm{u}$ \\
$3 \mathrm{r} / 2 \mathrm{u} / 2 \mathrm{a}$ & $\mathrm{ps}, \mathrm{d}$ & $\mathrm{ps}, \mathrm{e}, \mathrm{dr}, \mathrm{d}$ & $\mathrm{e}, \mathrm{u}$ \\
$2 \mathrm{r} / 2 \mathrm{u} / 2 \mathrm{a}$ & $\mathrm{ps}$ & $\mathrm{ps}, \mathrm{e}$ & $\mathrm{d}, \mathrm{e}, \mathrm{os}, \mathrm{u}$ \\
$3 \mathrm{u} / 3 \mathrm{a}$ & - & $\mathrm{d}, \mathrm{e}, \mathrm{g}, \mathrm{ps}, \mathrm{r}$ & - \\
$1 \mathrm{P}$ & - & - & \\
\hline
\end{tabular}

${ }^{1}$ grupo descarte de resíduos: r - potencial restrito, 2 - subgrupo resíduos inorgânicos atóxicos, 3 - subgrupo resíduos orgânicos atóxicos; grupo construções urbanas: u - potencial restrito, 2 - subgrupo comercial e residencial, 3 - subgrupo áreas verdes e recreativas; grupo agricultura urbana: a - potencial restrito, 2 - subgrupo olericultura e fruticultura, 3 - subgrupo silvicultura e/ou pastagem natural; grupo preservação ambiental: $1 \mathrm{P}$ - potencial adequado.

${ }^{2}$ ps - profundidade do solo; dr - drenagem do solo; g - material geológico; d - declividade do terreno; i - risco de inundações; pm permeabilidade do solo; r - rochosidade; e - suscetibilidade a erosão; ct - contaminação do solo; a - distância de cursos d’água, u - distância de área urbana.

O perímetro urbano de Santa Maria apresentou 52\% da área (6.491ha) com potencial de uso restrito a construções, restrito à agricultura urbana e inadequado para descarte de resíduos. Da mesma forma, 33\% do perímetro urbano de Santa Maria apresentou uso inadequado. A principal implicação ambiental do uso do espaço físico do perímetro urbano de Santa Maria sem o seu planejamento, desconsiderando o potencial de uso das terras, é a contaminação de solos e águas.

\section{APRESENTAÇÃO E AGRADECIMENTOS}

Parte da dissertação de mestrado do primeiro autor apresentada ao PPGCS da UFSM.

Os autores agradecem o auxílio financeiro concedido pela Fundação de Amparo à Pesquisa do Estado do Rio Grande do Sul (FAPERGS).

\section{REFERÊNCIAS}

ABNT. Associação Brasileira de Normas Técnicas. Aterros de resíduos não perigosos - critérios para projeto, implantação e operação. NBR 13.896. São Paulo, 1997. 21p.

ASSAD, M.L. Uso de um sistema de informações geográficas na determinação da aptidão agrícola de terras. Revista Brasileira de Ciência do Solo, Campinas, v.19, p.133-139, 1995.

BERGER, M.G. Uso do sensoriamento remoto na hierarquização das áreas de risco ambiental na subbacia hidrográfica do arroio Cadena, município de Santa Maria, RS. 2001. 144f. Dissertação (Mestrado em Engenharia Agrícola) - Programa de Pós-graduação em Engenharia Agrícola, Universidade Federal de Santa Maria.
BRASIL. Ministério das Cidades. Política nacional de desenvolvimento urbano. 2004. 92p. (Cadernos Cidades Desenvolvimento 1). Capturado em 14 jan. 2005. Online. Disponível na internet: http://www.cidades.gov.br

BURIOL, G.A. et al. Cartas mensais e anuais das temperaturas médias, das médias das temperaturas máximas e das médias das temperaturas mínimas do estado do Rio Grande do Sul. Revista do Centro de Ciências Rurais, Santa Maria, v.9, Suplemento, np., 1979.

CALLAI, H.C. A cidade e a (re)criação da relação homem natureza. Ciência \& Ambiente, Santa Maria, v.4, n.7, p.4353, 1993.

CAMARA, G. et al. SPRING: Integrating remote sensing and GIS by object-oriented data modelling. Computers \& Graphics, v.20, n.3, p.395-403, 1996.

CONAMA - Conselho Nacional do Meio Ambiente. Resolução n. 303, de 20 de março de 2002 - Dispõe sobre parâmetros, definições e limites de áreas de preservação permanente. Capturado em 15 set. 2004. Online. Disponível na internet: http://www.mma.gov.br/conama.

DA COSTA, S.M.F.; CINTRA, J.P. Environmental analysis of metropolitan areas in Brazil. Photogrammetry \& Remote Sensing, v.54, p.41-49, 1999.

DENT, D.; YOUNG, A. Soil survey and land evalution. London: E \& FN Spon, 1993. 284p.

EMBRAPA. Manual de métodos de análise de solos. Rio de Janeiro: EMBRAPA, 1997. 221p.

EMBRAPA. Procedimentos normativos de levantamentos pedológicos. Brasília: EMBRAPA, 1995. 116p.

EMBRAPA. Sistema brasileiro de classificação de solo. Brasília: EMBRAPA, 1999. 412p. 
IBGE. Instituto Brasileiro de Geografia e Estatística. Censo Demográfico 2000 para o município de Santa Maria, RS. Capturado em 13 jan. 2004. Online. Disponível na internet: http://www.ibge.gov.br.

INPE. Instituto Nacional de Pesquisas Espaciais. Sistema de Processamento de Informações Georeferenciadas, release 4.0. São José dos Campos, 2003. CD-ROM.

KLAMT, E. et al. Proposta de normas e critérios para execução de levantamentos semi-detalhados de solos e para avaliação da aptidão agrícola das terras. Pelotas: NRS-SBCS, 2000. 44p. (Boletim Técnico 5)

LEMOS, R.C.; SANTOS, R.D. Manual de descrição e coleta de solo no campo. Viçosa: SBCS, 2002. 83p.

MACIEL FILHO, C.L. Carta geotécnica de Santa Maria. Santa Maria: UFSM, 1990. 21p.

MACIEL FILHO, C.L. et al. Mapa geológico da folha de Camobi. Santa Maria: UFSM, 1988. 10p.

MILLER, R.B.; SMALL, C. Cities from the space: potencial applications of remote sensing in urban environmental research and policy. Environmental Science \& Policy, v.267, p.1-9, 2003.

PEDRON, F. de A. Classificação do potencial de uso das terras no perímetro urbano de Santa Maria - RS. 2005. 74f.
Dissertação (Mestrado em Ciência do Solo) - Programa de Pósgraduação em Ciência do Solo, Universidade Federal de Santa Maria.

PEDRON, F. de A. et al. Variabilidade e a aptidão agrícola de Argissolos na Depressão Central do Rio Grande do Sul. In. REUNIÃO SUL-BRASILEIRA DE CIÊNCIA DO SOLO, 5., 2004, Florianópolis, SC. Anais... Florianópolis: SBCS - NRS, 2004. 4p. (CD-ROM)

PIROLI, E.L. et al. Análise do uso da terra na microbacia do Arroio do Meio por sistema de informações geográficas e imagens de satélite. Ciência Rural, Santa Maria, v.32, n.3, p.407-413, 2002

ROBAINA, L.E. et al. Análise dos ambientes urbanos de risco do município de Santa Maria - RS. Ciência \& Natura, Santa Maria, v.23, p.139-152, 2001.

ROSSATO, R. Cidades brasileiras: a urbanização patológica. Ciência \& Ambiente, Santa Maria, v.7, p.23-32, 1993.

URRUTIA, R.A. Urbanização: crescimento da área urbana, espaços ociosos e especulação imobiliária no município de Santa Maria - 1980/2000. 2002. $65 f$. Monografia (Especialização em História do Brasil) - Programa de Pós-graduação em História do Brasil, Universidade Federal de Santa Maria. 